\title{
Effect of Aging Time on the Microstructural Characterization and Corrosion Resistance of Al-4.5Cu-1Li-0.4Mg-0.4Ag-0.4Mn-0.5Zn Alloys
}

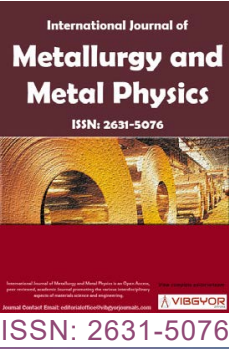

Wenzheng Chen ${ }^{1}$, Dongyan Ding ${ }^{1 *}$, Wenlong Zhang ${ }^{1}$ and Daihong Xiao ${ }^{2}$

${ }^{1}$ School of Materials Science and Engineering, Shanghai Jiao Tong University, China

${ }^{2}$ Science and Technology on High Strength Structural Materials Laboratory, Central South University, China

\begin{abstract}
Alloying based on Al-Li alloys plays an important factor for an adjustment of microstructure as well as corrosion behavior. In this study, we mainly focus on microstructural evolution of Al-4.5Cu- $1 \mathrm{Li}-0.4 \mathrm{Mg}$ $0.4 \mathrm{Ag}-0.4 \mathrm{Mn}-0.5 \mathrm{Zn}$ alloy during homogenization and aging treatment. Microstructure and composition of the homogenized alloys and aged alloys were investigated. The homogenized alloys were mainly composed of $\mathrm{Al}(\alpha), \mathrm{Al}_{7} \mathrm{Cu}_{4} \mathrm{Li}, \mathrm{Al}_{3} \mathrm{Li}$ and $\mathrm{Al}_{2} \mathrm{CuLi}$ precipitates. All precipitates coarsened with increase of homogenization temperature and holding time. Peak-age could realize when the homogenized and solution-treated alloy was aged at $120^{\circ} \mathrm{C}$ for 4 hours and then $180^{\circ} \mathrm{C}$ for 10 hours. The peak-age alloy was mainly composed of $\mathrm{Al}_{2} \mathrm{CuLi}, \mathrm{Al}_{20} \mathrm{Cu}_{2} \mathrm{Mn}_{3}$ and $\mathrm{Cu}$-rich precipitates. In the $0.5 \% \mathrm{NaCl}$ solution, corrosion potential and corrosion current density of the peak-age alloy were $-573 \mathrm{mV}$ and $1.028 \mu \mathrm{A} / \mathrm{cm}^{2}$, respectively. And the overage alloy had more positive current potential of $-557 \mathrm{mV}$ and higher corrosion density of $4.487 \mu \mathrm{A} / \mathrm{cm}^{2}$. In the $3.5 \% \mathrm{NaCl}$ solution, Tafel polarization of the peak-age alloy revealed the corrosion potential and corrosion current density to be $-611 \mathrm{mV}$ and $2.005 \mu \mathrm{A} / \mathrm{cm}^{2}$, respectively. The over-age alloy had more negative corrosion potential of $-653 \mathrm{mV}$.
\end{abstract}

Keywords

Al-Cu-Li alloy, Homogenization, Aging, Microstructure, Corrosion behavior

\section{Introduction}

Al-Li alloys have been developed for 80 years and experienced three symbolic stages of development. Invention of 2020 alloy (by Alcoa, America) in 1957 symbolized the first-generation development of Al-Li alloys [1]. The Li content in 2020 alloys was 1 wt.\% which could reduce $6 \%$ weight of the aluminum alloy. And 2020 alloy had high creep resistance in high temperature. Development of 1420 (by Russia) and 2090 (by Alcoa, America) alloys marked the beginning of the second stage develop- ment of Al-Li alloys [2], and the feature of the alloys at second development stage was that Li content of Al-Li alloys was higher than 1.9 wt.\%. Shortcoming of such kind of alloys was obvious, i.e., low plasticity and bad machinability. Therefore, application of second stage Al-Li alloys was not wide. After 1990s, the development of Al-Li alloys entered the third generation. The third stage Al-Li alloys had relatively low content of Li (no more than $2 \mathrm{wt} . \%$ ) and were optimized by alloying. Moreover, the contents of $\mathrm{Fe}$ and $\mathrm{Si}$ in third stage Al-Li alloys were strictly re-

*Corresponding author: Dongyan Ding, School of Materials Science and Engineering, Shanghai Jiao Tong University, Shanghai 200240, China, Tel: +86-21-3420 2741

Accepted: March 20, 2021; Published: March 22, 2021

Copyright: (C) 2021 ChenW, et al. This is an open-access article distributed under the terms of the Creative Commons Attribution License, which permits unrestricted use, distribution, and reproduction in any medium, provided the original author and source are credited.

Chen et al. Int J Metall Met Phys 2021, 6:066

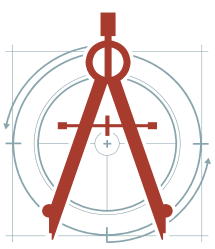


stricted to avoid coarse grains. And, alloying with $\mathrm{Mg}$ and $\mathrm{Ag}$ in third stage Al-Li alloys could increase the effect of aging strengthening. Classic third generation alloys such as 2099, 2199, 2196, 2098 alloys (by Alcoa, America), 1469, 1464 and 1460 alloys (by Russia) were widely produced and used [3]. Now we are encountering with the fourth development stage of Al-Li alloys. In this stage, researchers adjusted the ratio of $\mathrm{Cu}$ : $\mathrm{Li}$ in Al-Cu-Li alloys and alloyed with $\mathrm{Zn}, \mathrm{Mn}, \mathrm{Ce}$ and so on to optimize toughness of Al-Li alloys [4].

Commonly, as-cast Al-Li alloys had bad mechanical property due to coarse dendrites. Peng, et al. [5] reported that alloying with $\mathrm{Zr}$ could make the grains of Al-Li alloys become isometric, and primary and secondary dendrite arm space of Al-Li alloys could be reduced. $\mathrm{Yu}$, et al. [6] also reported that precipitates in as-cast $\mathrm{Al}-\mathrm{Li}-\mathrm{Mg}$ - $\mathrm{Cu}-\mathrm{Zr}$ alloy were different for different ratio of $\mathrm{Cu}$ and $\mathrm{Mg}$. When the ratio of $\mathrm{Cu}: \mathrm{Mg}$ was higher than 6: 1, the alloy was mainly composed of $\alpha(\mathrm{Al}), \mathrm{T} 2\left(\mathrm{Al}_{6} \mathrm{CuLi}_{3}\right)$ and coarse $\mathrm{Al}_{4} \mathrm{Cu}_{9}$. Coarse precipitates along grain boundaries made grain boundaries of the alloy weaken.

Aging treatment could make grains and precipitates of $\mathrm{Al}-\mathrm{Li}$ alloys become fine and scattered. And second precipitates vary from different chemical composition of Al-Li alloys. Generally, secondary precipitates included equilibrium precipitate and non-equilibrium precipitate. Zhao, et al. [7] reported that $\mathrm{T}_{1}\left(\mathrm{Al}_{2} \mathrm{CuLi}\right)$ in 2198 alloy had better strengthening effect than $\theta^{\prime}\left(\mathrm{Al}_{2} \mathrm{Cu}\right)$ did. Because $\delta^{\prime}\left(\mathrm{Al}_{3} \mathrm{Li}\right)$ precipitate is ordered coherent with $\mathrm{Al}$ matrix, the particles are easy to be cut by dislocations. $\mathrm{T} 1\left(\mathrm{Al}_{2} \mathrm{CuLi}\right)$ presented as needle-like precipitates and was oriented with $\mathrm{Al}$ matrix. Relation between $\mathrm{T} 1$ ( $\left.\mathrm{Al}_{2} \mathrm{CuLi}\right)$ and $\mathrm{Al}$ matrix is $\left\{\begin{array}{llll}0 & 0 & 0 & 1\end{array}\right\} T 1 / /\left\{\begin{array}{lll}1 & 1 & 1\end{array}\right\}_{\alpha},\langle 1 \overline{1} 00\rangle T 1 / /\langle 1 \overline{1} 0\rangle_{\alpha .}$. Therefore, $\mathrm{T} 1\left(\mathrm{Al}_{2} \mathrm{CuLi}\right)$ precipitates could make AlLi alloys be anisotropic $[4,8]$.

Nowadays, development of Al-Li alloy is confronted with a big difficulty which is the immature smelting technology. The biggest problem is hydrogen adsorption because of Li element in the alloy. Lee, et al. [9] reported that over-aged Al-1.9Li alloy had the least hydrogen-assisted cracking susceptibility. Saikawa, et al. [10] thought that the size and shape of porosities in as-cast Al-Li alloys would be changed with different hydrogen gas content. And the main reason of brittle fracture of Al- $\mathrm{Li}$ alloys was probably caused by lithium hydride. To date, there are some methods to recede brittle fracture caused by hydrogen adsorption like vacuum smelting and alloying refining agent.

Another way to optimize mechanical property of $\mathrm{Al}-\mathrm{Li}$ alloys is heating treatment. Homogenization could effectively reduce shrinkage, porosity and segregation in the as-cast alloys. Gupta, et al. [11] reported that two-stage homogenization could reduce precipitation at grains boundaries which could improve binding force of grain boundaries. Pitcher, et al. [12] reported that two-stage aging treatment could facilitate precipitation of $\mathrm{S}^{\prime}\left(\mathrm{Al}_{2} \mathrm{MgLi}\right)$ precipitates and made precipitates be scattered. Two-stage aging treatment could separate into two steps, which were low temperature stage and high-temperature stage. During the first stage of aging treatment, Al-Li alloy was treated at low temperature and formed Guinier Preston (GP) zone. After the alloy was treated at high temperature, precipitates became scattered and finer. Cina, et al. [13] reported that retrogression and re-aging (RRA) treatment could be conducted on Al-Cu-MgZn alloy. And Ahmadi, et al. [14] also reported that retrogression re-aging treatment could facilitate precipitation of $\mathrm{T} 1\left(\mathrm{Al}_{2} \mathrm{CuLi}\right)$ in $\mathrm{Al}-\mathrm{Li}$ alloy, which proved that retrogression re-aging treatment could optimize the property of Al-Li alloys.

Some researchers have been conducted on Al-Cu-Li based alloy. Liu, et al. [15] reported microstructural evolution of Al-3.8Cu-1.28Li-0.4Mg$0.4 \mathrm{Ag}-0.4 \mathrm{Zn}-0.1 \mathrm{Zr}-0.05 \mathrm{Ti}$ during two-stage homogenization treatment. In the present work, we fabricated $\mathrm{Al}-4.5 \mathrm{Cu}-1.0 \mathrm{Li}-0.4 \mathrm{Mg}-0.4 \mathrm{Ag}-0.4 \mathrm{Mn}-0.5 \mathrm{Zn}$ $-0.13 \mathrm{Zr}-0.1 \mathrm{Ti}$ alloy through single-step homogenization treatment at different temperature, and aging treatment of extruded alloys. Microstructure and corrosion resistance of the alloy was investigated.

\section{Experimental Procedure}

The alloy (Al-4.5Cu-1.0Li-0.4Mg-0.4Ag-0.4Mn$0.5 \mathrm{Zn}-0.13 \mathrm{Zr}-\mathrm{-}-1 \mathrm{Ti}$ ) was fabricated through vacuum melting. DSC (differential scanning calorimetry) testing of the alloys was conducted with Simultaneous Thermal Analyzer (STA 449 F3, NETZSCH, Germany) to identify melting point and optimize the homogenization temperature. The homogenized alloys were cut into $10 \mathrm{~mm} \times 10 \mathrm{~mm} \times 10 \mathrm{~mm}$ cubes and embedded in epoxy resin. After ensuring the 


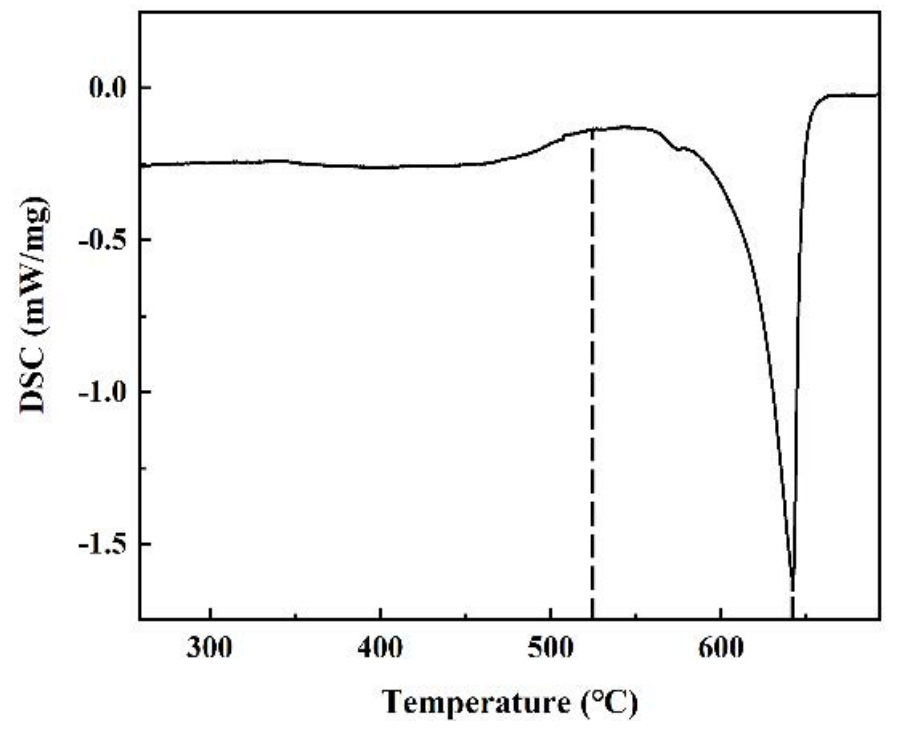

Figure 1: DSC curve of the Al-4.5Cu-1Li-0.4Mg-0.4Ag-0.4Mn-0.5Zn alloys.

suitable homogenization temperature, the ingots were homogenized at different temperatures for different holding time.

The homogenized alloys were hot-extruded and solution treated at $520{ }^{\circ} \mathrm{C}$ for 2 hours and then quenched by water. The supersaturated solid solutions were cut into thickness of $20 \mathrm{~mm}$ column, which were then subjected to two-stage aging treatments. In the two-stage aging, aging was performed first at $120{ }^{\circ} \mathrm{C}$ for 4 hours and then at $180{ }^{\circ} \mathrm{C}$ for different periods $(4,6,8,10,12,14,16$ hours). The hardness of the aged alloys was tested by microhardness tester (400SXV, Shanghai Shangcai, China), and the testing force was $1 \mathrm{~kg}$, holding time was 10 seconds. The metal surfaces of the homogenized alloys or the aged alloys were grinded by metallographic sandpapers and polished by polishing agent. The polishing agent was composed of ethanol and $\mathrm{MgO}$ particles. The precipitates of the homogenized alloys and the aged alloys were investigated with Low Vacuum Ultra-High-Resolution Field Emission Scanning Electron Microscope (SEM) (NOVA nano SEM 230, FEI, Oregon, USA). To identify the precipitates, the homogenized alloys and the aged alloys were characterized with X-ray diffraction (XRD) instrument (max2500, Rigaku D, Japan, $\mathrm{Cu}$ target) and Energy Dispersive Spectrometer (EDS) instrument (NOVA nano SEM 230, FEI, Oregon, USA). The peak-age alloys were thinned by ion thinning instrument (PIPS 695, Gatan, USA) for transmission electron microscope (TEM) investigating. Microstructure of the aged alloys was analyzed with field emission transmission electron microscope (TALOS F200X, FEI, Oregon, USA).

Tafel polarization test was conducted by electrochemical workstation ( $\mathrm{CHI} 660 \mathrm{E}$, Shanghai Chenhua, China). Three parallel experiments were carried out and typical testing curve was used to evaluate the corrosion resistance. The electrolyte was $3.5 \% \mathrm{NaCl}$ solution and $0.5 \% \mathrm{NaCl}$ solution. The testing range was from $-1 \mathrm{~V}$ to $0 \mathrm{~V}$ and scan rate was $0.001 \mathrm{~V} / \mathrm{s}$. The reference electrode was saturated calomel electrode and auxiliary electrode was platinum. And the working electrode was the sample. All potentials were relative to the reference electrode (saturated calomel electrode). Field-emission Scanning Electron Microscope (Sirion 200, FEI, Oregon, USA) were used to observe the corrosion surface of the aged alloys.

\section{Results and Discussion}

\section{Homogenized states}

The alloys were $\mathrm{Al}-4.5 \mathrm{Cu}-1.0 \mathrm{Li}$ alloying with 0.4 wt.\% Mg, 0.4 wt.\% Ag, 0.4 wt.\% Mn, 0.5 wt.\% Zn, 0.13 wt.\% $\mathrm{Zr}$, and $0.1 \mathrm{wt} . \% \mathrm{Ti}$. As shown in DSC curve of the alloy (Figure 1), the initial inflection point of endothermic peak was around $525^{\circ} \mathrm{C}$. Thus, we can identify the initial melting point of eutectic precipitates was $525^{\circ} \mathrm{C}$, and the melting point was around $640{ }^{\circ} \mathrm{C}$, which is the endothermic peak. As a result, the homogenization temperature set at $500{ }^{\circ} \mathrm{C}$ and $515^{\circ} \mathrm{C}$ can adequately make the alloys homogenize and avoid over-burning.

SEM images of the homogenized alloys with dif- 

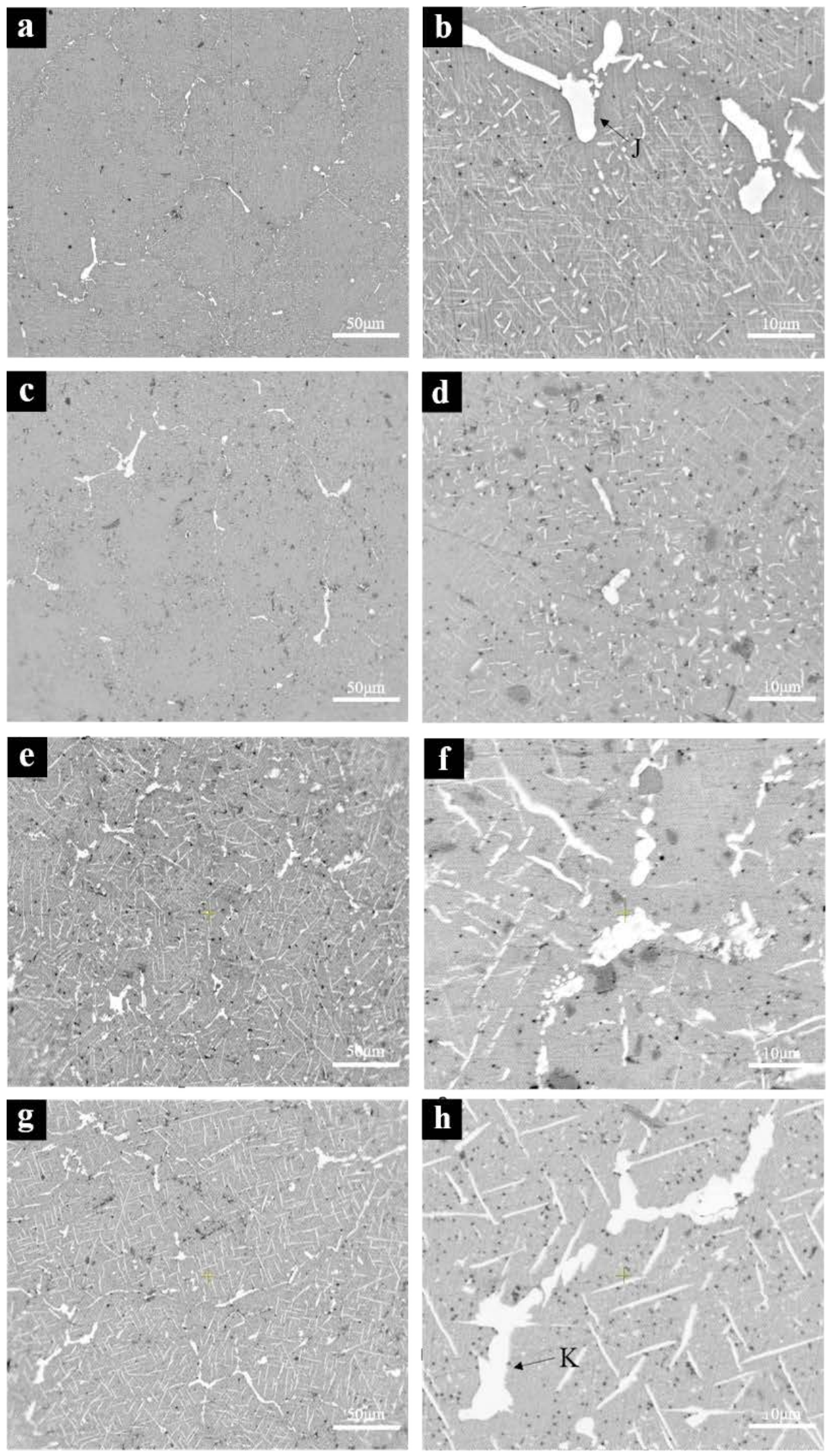

Figure 2: Low-magnification and high-magnification SEM images of the alloys homogenized at: $(a, b) 500{ }^{\circ} \mathrm{C}$ for 8 hours; (c,d) $515^{\circ} \mathrm{C}$ for 8 hours; (e,f) $500^{\circ} \mathrm{C}$ for 20 hours; (g,h) $515^{\circ} \mathrm{C}$ for 20 hours. 
ferent homogenization treatment were shown in Figure 2. It can be seen from Figure 2a and Figure $2 c$ that the bone-like precipitates at grain boundaries coarsened with the increase of homogenization temperature. As the holding time increased from 8 hours to 20 hours (Figure $2 b$ and Figure $2 f$ ), many of needle-like phases located in the matrix obviously coarsened. Meanwhile, after prolonging the holding time and increasing homogenization temperature, the distribution density of dot-like precipitates in Figure $2 \mathrm{~h}$ were more than those in Figure 2b.

XRD pattern in Figure 3 revealed that $\mathrm{Al}_{7} \mathrm{Cu}_{4} \mathrm{Li}$ phases existed in the homogenized alloys and the peak intensity of the phase was enhanced with the increasing temperature and holding time, which indicates that the content of $\mathrm{Al}_{7} \mathrm{Cu}_{4} \mathrm{Li}$ phases increased. Table 1 presented the element composition of the bone-like precipitates shown in Figure 2. Al:Cu atom ratio of appointed bone-like precipitate $\mathrm{J}$ in Figure $2 \mathrm{~b}$ was nearly $7: 4$, which means that the bone-like precipitate are mainly composed by $\mathrm{Al}$ and $\mathrm{Cu}$ elements. And according to the research [16], $\mathrm{Al}_{7} \mathrm{Cu}_{4} \mathrm{Li}$ precipitates tend to precipitate at grain boundaries. Hence, it could be inferred that the bone-like precipitates $\mathrm{J}$ were $\mathrm{Al}_{7} \mathrm{Cu}_{4} \mathrm{Li}$ phases. Moreover, as shown in Figure $2 \mathrm{~h}$, the bone-like precipitates coarsened with increase of homogenization temperature and holding time, and the marked phase $\mathrm{K}$ could be also identified as $\mathrm{Al}_{7} \mathrm{Cu}_{4}$ Li phase. According to phases morphology features and resent researches [17], the distributed dot-like particles were $\mathrm{Al}_{3} \mathrm{Li}$ and the oriented bright needle-like precipitates were $\mathrm{Al}_{2} \mathrm{CuLi}$. Existence of the $\mathrm{Al}_{2} \mathrm{CuLi}$ phases can be also found according to the XRD pattern in Figure 3. With the increase of homogenization temperature and holding time, the peak of $\mathrm{Al}_{2} \mathrm{CuLi}$ phase was intensified, which means that the content of $\mathrm{Al}_{2} \mathrm{CuLi}$ phases increased. Figure $2 \mathrm{e}$, Figure $2 \mathrm{f}$, Figure $2 \mathrm{~g}$ and Figure $2 \mathrm{~h}$ also revealed that the needle-like phases coarsened as the homogenization temperature and holding time increased.

During the casting process, few $\mathrm{Al}_{7} \mathrm{Cu}_{4} \mathrm{Li}$ precipitates precipitated at grain boundaries. As the homogenization proceeds, $\mathrm{Al}_{7} \mathrm{Cu}_{4} \mathrm{Li}$ precipitates grew up. The higher the homogenizing temperature was, or longer the holding time was, the $\mathrm{Al}_{7} \mathrm{Cu}_{4} \mathrm{Li}$ precip-

Table 1: Chemical composition of marked phases of homogenized alloys. (Li cannot be detected).

\begin{tabular}{|l|l|l|l|l|l|l|l|l|}
\hline Phases & Mg & Al & Mn & Cu & Zr & Ag & Zn & Ti \\
\hline J, wt.\% & 2.45 & 59.57 & 0.18 & 31.77 & 0.05 & 0.05 & 5.92 & 0.00 \\
\hline K, wt.\% & 0.22 & 61.06 & 2.90 & 32.56 & 0.00 & 0.06 & 3.18 & 0.02 \\
\hline
\end{tabular}

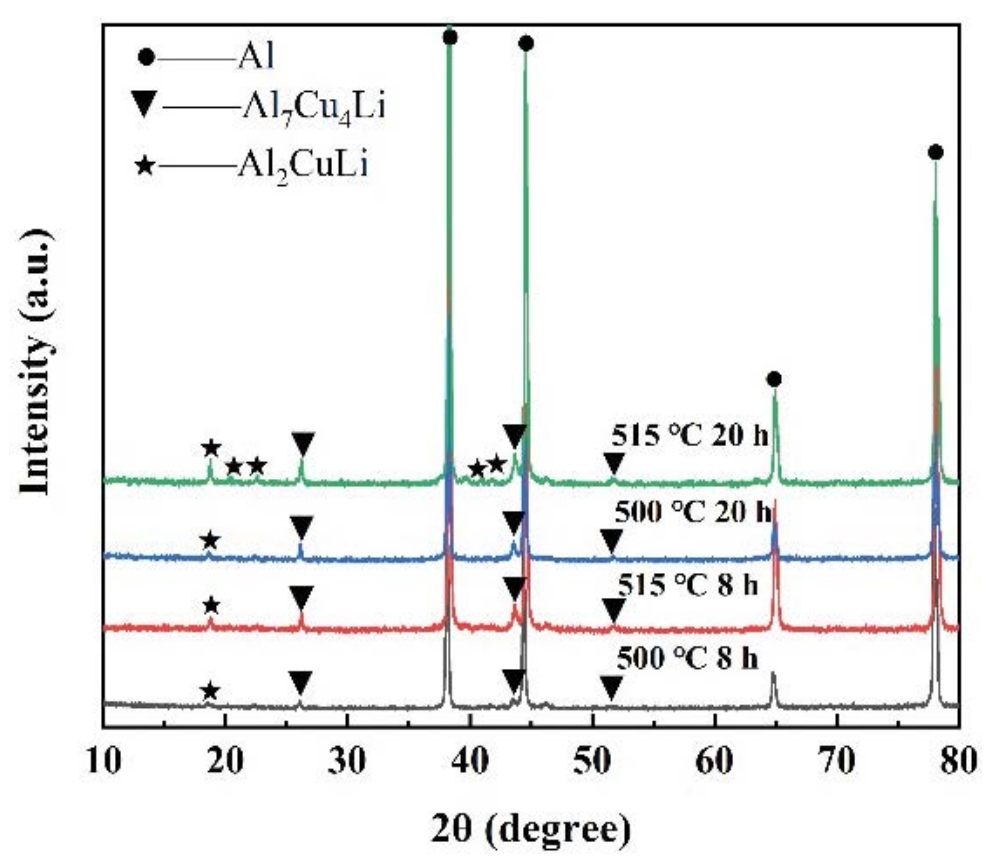

Figure 3: XRD pattern of the alloys homogenized at different temperature for different time. 

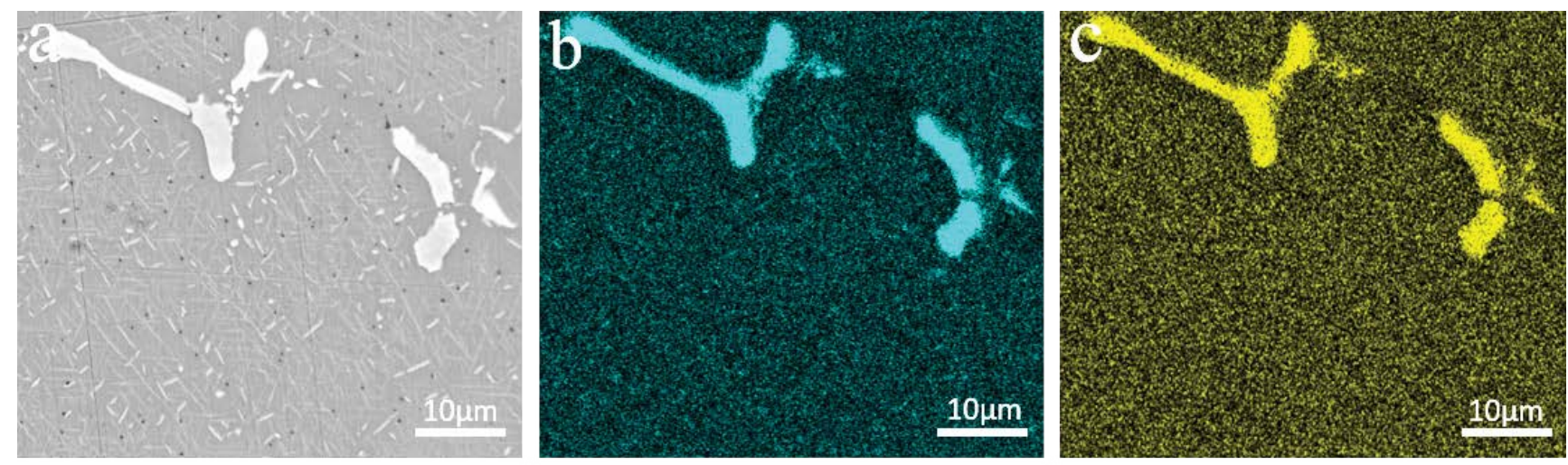

Figure 4: (a) SEM image and elemental mapping of the alloy homogenized at $500{ }^{\circ} \mathrm{C}$ for 8 hours; (b) Cu element; (c) Zn element.
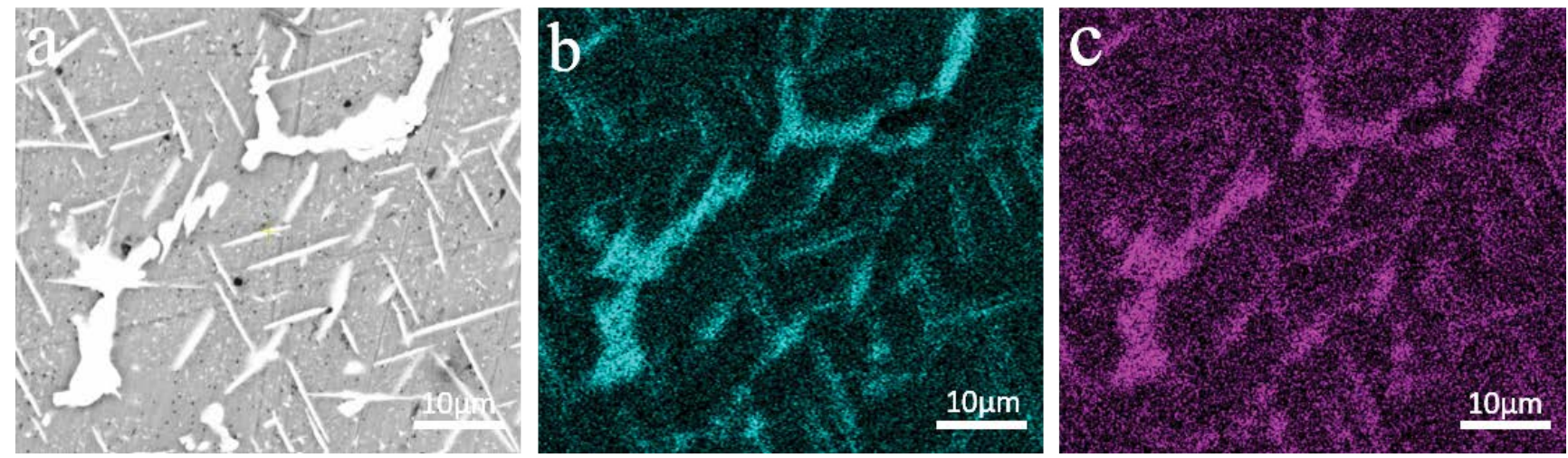

Figure 5: (a) SEM image and elemental mapping of the alloy homogenized at $515{ }^{\circ} \mathrm{C}$ for 20 hours; (b) Cu element; (c) Zn element.

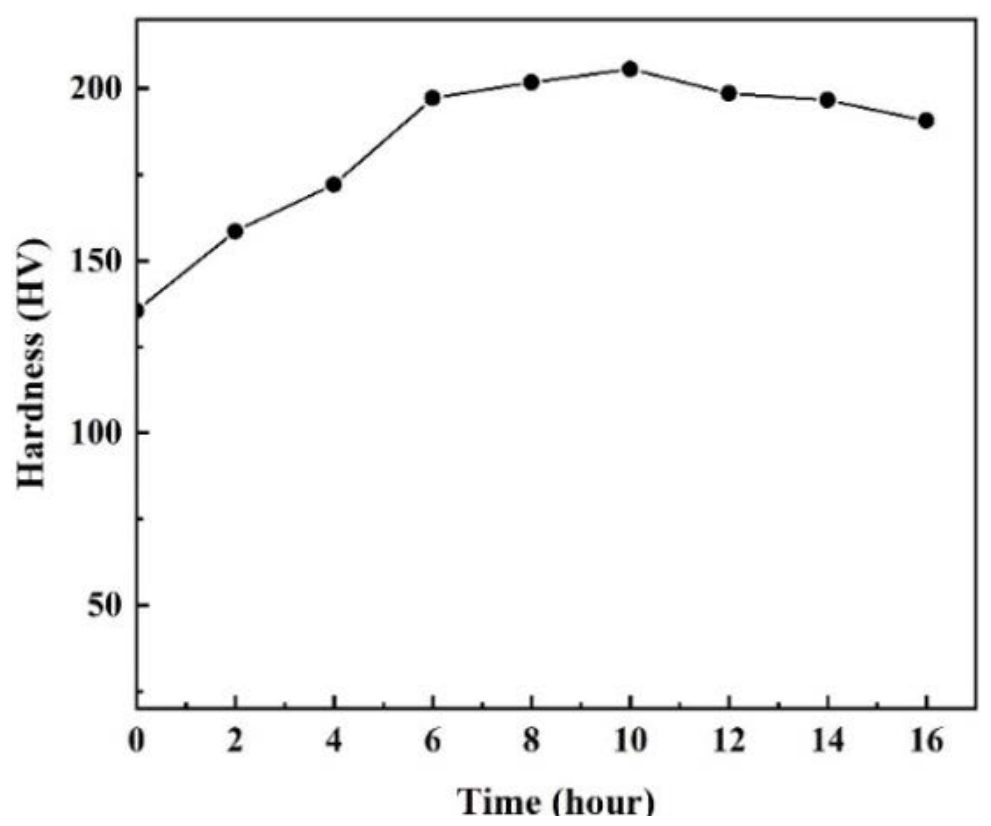

Figure 6: Aging curve of the alloys. 

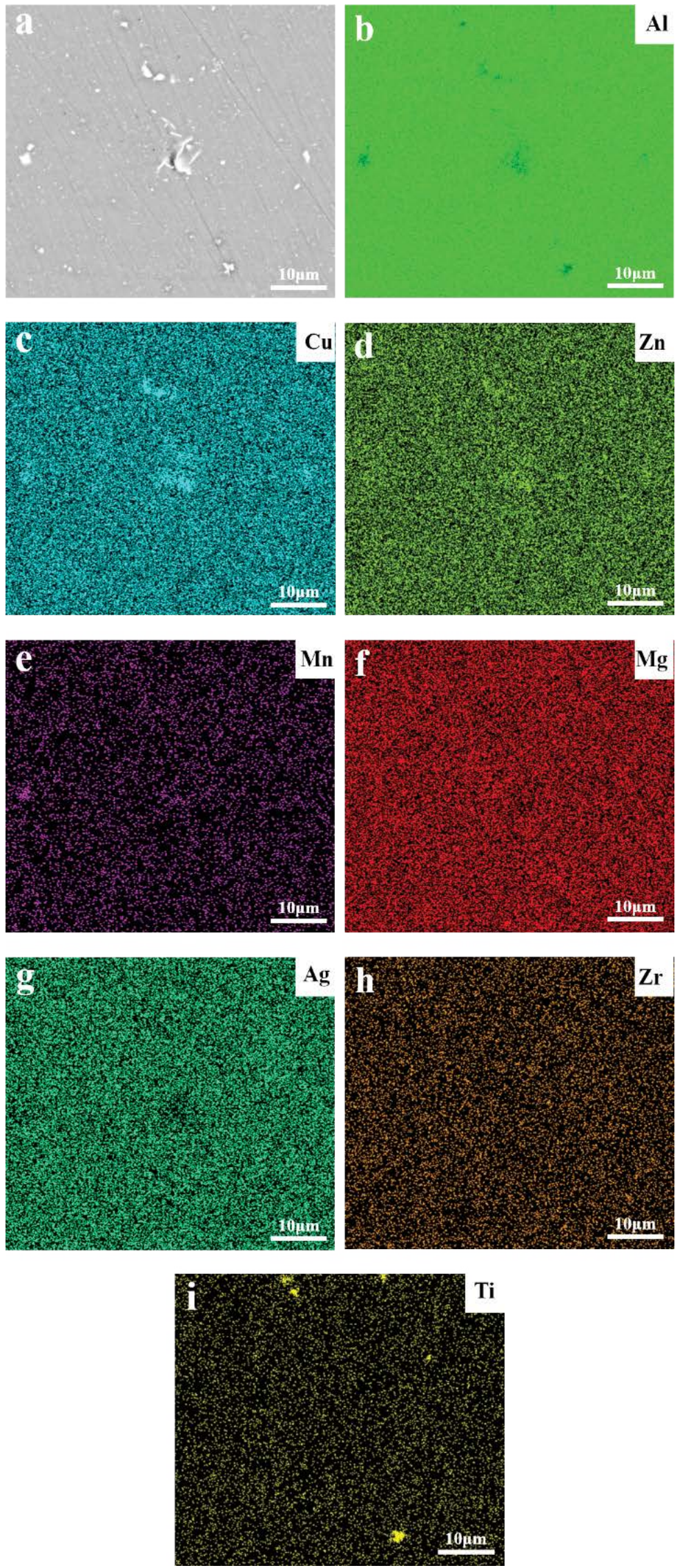

Figure 7: (a) Backscattered electron images of aged alloys and elemental mapping images of the aged alloys; (b) Al; (c) Cu; (d) Zn; (e) Mn; (f) Mg; (g) Ag; (h) Zr; (i) Ti element. 
itates became coarsen. Meanwhile, the needle-like $\mathrm{Al}_{2} \mathrm{CuLi}$ precipitates were also longer and more coarsened and distribution density of the dot-like $\mathrm{Al}_{3} \mathrm{Li}$ particles became higher with increase of the holding time and the homogenization temperature.

As shown in Figure 4 and Figure 5, segregation of $\mathrm{Cu}$ and $\mathrm{Zn}$ elemental both existed in the alloy homogenized at either $500^{\circ} \mathrm{C}$ for 8 hours or $515^{\circ} \mathrm{C}$ for 20 hours, which indicates that $\mathrm{Zn}$ segregation could not be avoided by increasing homogenization temperature and holding time. And the $\mathrm{Zn}$ segregation could be found at large bone-like precipitates and needle-like precipitates in the alloy homogenized at $515{ }^{\circ} \mathrm{C}$ for 20 hours. Kilmer, et al. [18] reported that the binding force between $\mathrm{Cu}$ atom and $\mathrm{Zn}$ atom were powerful, so that $\mathrm{Cu}-\mathrm{Zn}$ clusters formed and decreased the solubility of $\mathrm{Cu}$ element. As a result, the precipitation of $\mathrm{Cu}$-rich precipitates could be facilitated by alloying $\mathrm{Zn}$ element. It could be inferred that alloying $\mathrm{Zn}$ element decrease solubility of $\mathrm{Cu}$ element and restrained the dissolving of Al${ }_{7} \mathrm{Cu}_{4} \mathrm{Li}$ during homogenization. And some researchers [19] also reported that the combined effect of alloying $\mathrm{Zn}$ and $\mathrm{Mg}$ could facilitate the nucleation of $\mathrm{Al}_{3} \mathrm{Li}$ and $\mathrm{Al}_{2} \mathrm{CuLi}$ precipitates. Thus, increase content of $\mathrm{Al}_{3} \mathrm{Li}$ and $\mathrm{Al}_{2} \mathrm{CuLi}$ during homogenization was attributed to the alloying with $\mathrm{Zn}$ element.

\section{Aging state}

The alloys were solution treated and aged at 120 ${ }^{\circ} \mathrm{C}$ for 4 hours and $180{ }^{\circ} \mathrm{C}$ for different time. Microhardness of the aged alloys were shown in Figure 6.
As the aging time increased, the hardness initially increased until it approached the maximum and then gradually decreased. The peak-age could be realized when the alloy was aged at $120{ }^{\circ} \mathrm{C}$ for 4 hours and $180^{\circ} \mathrm{C}$ for 10 hours, and hardness of the peak-age alloy was $205 \mathrm{HV}$.

Figure 7 showed the backscattered electron images and elemental mapping of the peak-age alloy. In Figure $7 d$, the $\mathrm{Zn}$ segregation still existed at $\mathrm{Cu}$ rich precipitates. Compared with the homogenized alloys, it could be found that segregation of the $\mathrm{Mn}$ element showed up at precipitates (in Figure 7e). In Figure 7f, Figure 7g and Figure 7h, distribution of $\mathrm{Mg}, \mathrm{Ag}$ and $\mathrm{Zr}$ elements were uniform in the peakage alloy. As shown in Figure 7i, Ti-rich particles were found at some area, and the particles could be identified as $\mathrm{Al}_{3}$ Ti precipitates [20].

SEM images of the peak-age alloy shown in Figure 8 , which indicates that there were some residual precipitates in the peak-age alloy. In Figure 8b, the precipitates were arrowed as $\mathrm{N}, \mathrm{L}$ and $\mathrm{M}$. Table 2 presented chemical composition of the marked precipitates. It could be found the $\mathrm{Al}$ and $\mathrm{Cu}$ were the main composition of the $\mathrm{L}, \mathrm{M}$ and $\mathrm{N}$ precipitates. So, the precipitates arrowed by $L, M$ and $N$ could be identified as $\mathrm{Cu}$-rich precipitates. Moreover, the precipitate $\mathrm{N}$ had relatively higher content of $\mathrm{Mn}$, which suggested that there $\mathrm{Mn}$-rich precipitation at the $\mathrm{Cu}$-rich precipitates. In Figure 8a, there were many tiny particles in area 0 . To identify the tiny particles, TEM analyses were investigated.
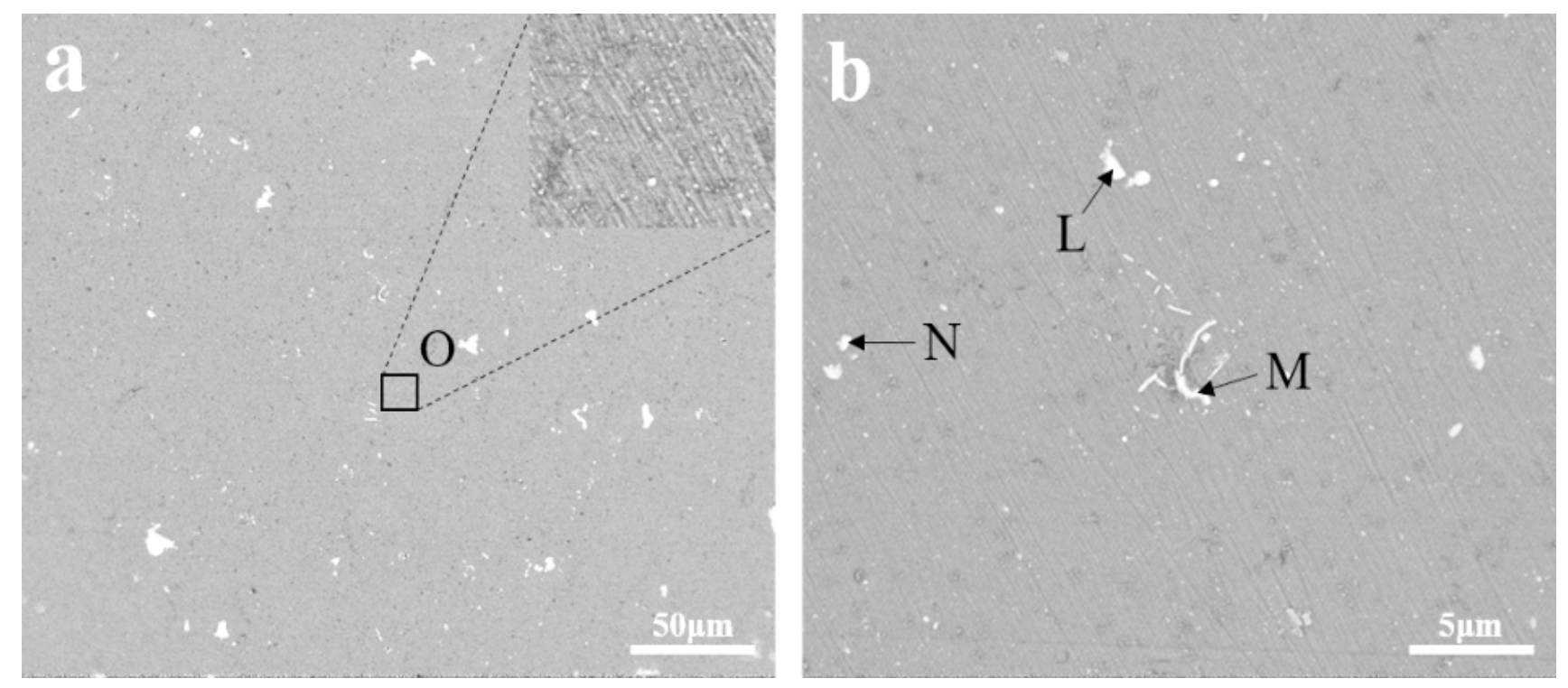

Figure 8: SEM images of the peak-age alloy: (a) Magnification image; (b) Microstructure of the peak-age alloy. 
Table 2: Chemical composition of the arrowed precipitates in the peak-age alloys. (Li cannot be detected).

\begin{tabular}{|l|l|l|l|l|l|l|l|l|}
\hline Phases & Mg & Al & Mn & Cu & Zr & Ag & Zn & Ti \\
\hline L, wt.\% & 0.56 & 79.44 & 1.48 & 12.74 & 0.00 & 0.01 & 5.74 & 0.02 \\
\hline M, wt.\% & 0.50 & 79.35 & 1.01 & 11.68 & 0.00 & 0.07 & 7.35 & 0.00 \\
\hline N, wt.\% & 0.46 & 79.62 & 4.41 & 9.35 & 0.40 & 0.09 & 5.68 & 0.00 \\
\hline
\end{tabular}
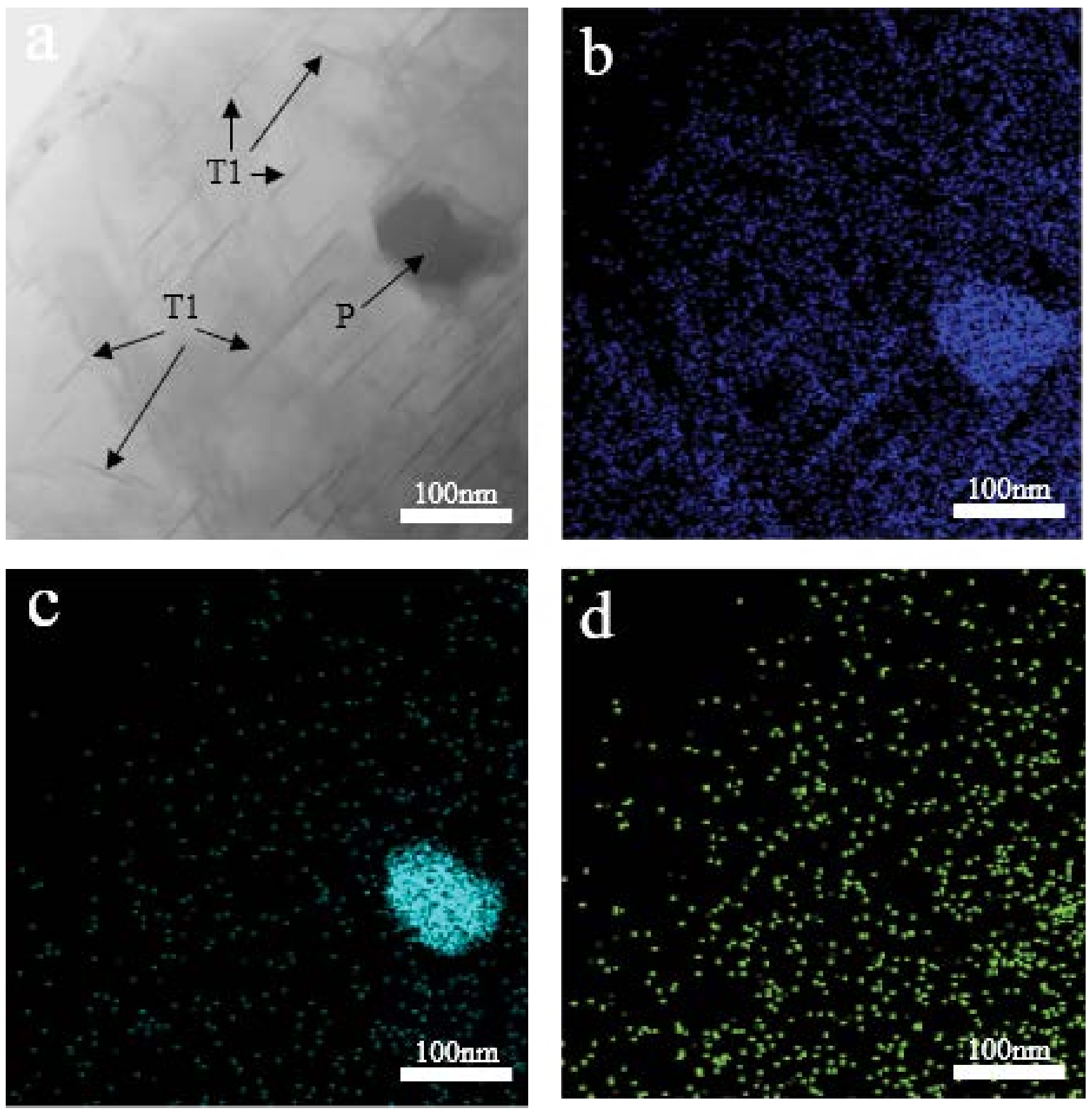

Figure 9: TEM images of the peak-age alloy: (a) Nanoscale precipitates and elemental mapping of the peak-age alloy; (b) Cu; (c) Mn; (d) Al.

Figure 9a showed the TEM image of the peakage alloy. As shown in Figure 9a, there were many needle-like precipitates and particles. Figure $9 \mathrm{~b}$ revealed that either needle-like precipitates or par- ticles, which means that those precipitates were Al-Cu containing precipitates. According to Wang, et al. [21], the oriented needle-like precipitates could be identified as $\mathrm{Al}_{2} \mathrm{CuLi}$ which precipitated 
Table 3: Tafel polarization parameters of aged Al-Li alloys tested in the $0.5 \% \mathrm{NaCl}$ solution.

\begin{tabular}{|c|c|c|c|c|c|}
\hline Alloy & $\begin{array}{l}E_{\text {corr }} \\
\text { (mV vs. SCE) }\end{array}$ & $\begin{array}{l}I_{\text {corr }} \\
\left(\mu \mathrm{A} / \mathrm{cm}^{2}\right)\end{array}$ & Alloy & $\begin{array}{l}E_{\text {corr }} \\
\text { (mV vs. SCE) }\end{array}$ & $\begin{array}{l}I_{\text {corr }} \\
\left(\mu \mathrm{A} / \mathrm{cm}^{2}\right)\end{array}$ \\
\hline Peak-age alloy & -573 & 1.028 & Peak-age alloy & -611 & 2.005 \\
\hline Over-age alloy & -557 & 4.487 & Over-age alloy & -653 & 3.575 \\
\hline
\end{tabular}

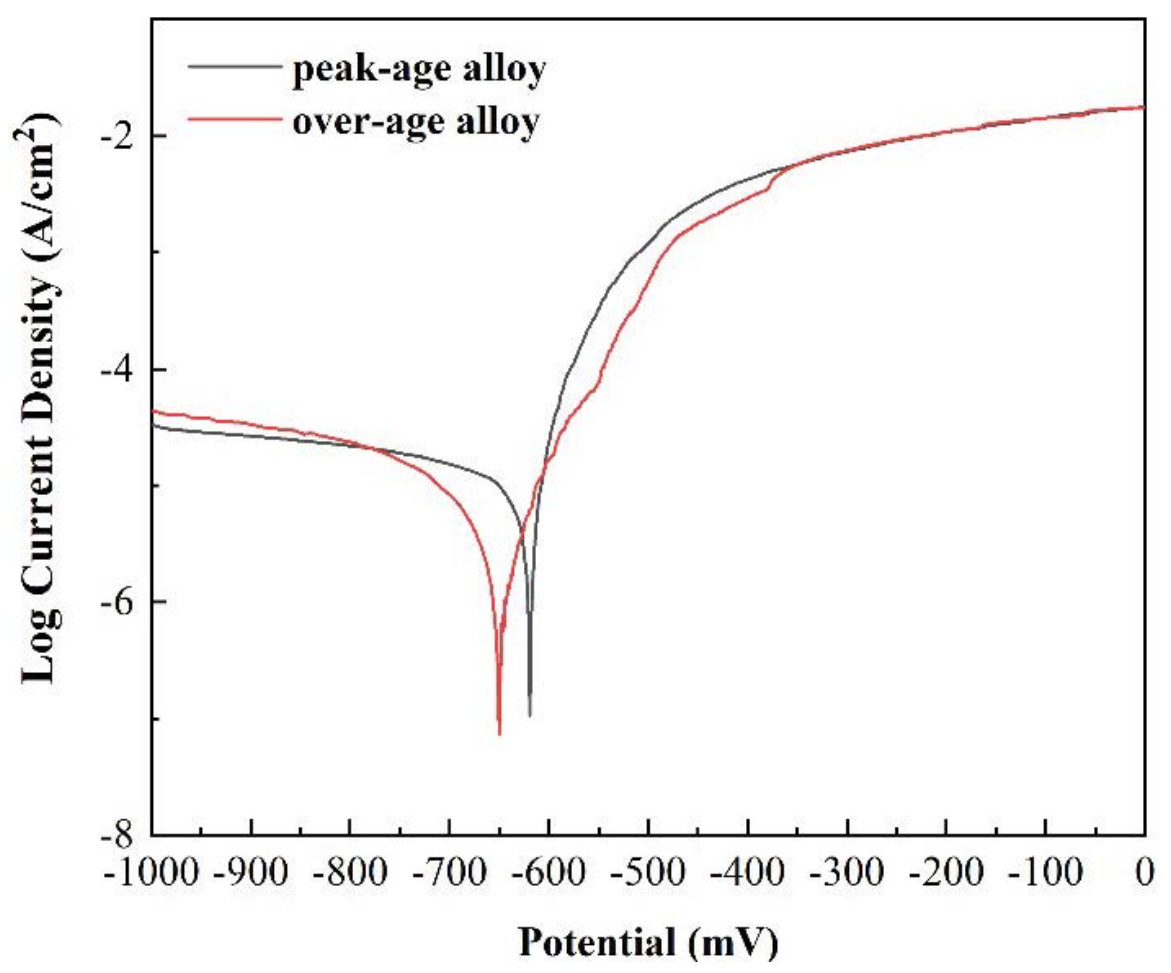

Figure 10: Typical Tafel polarization curve of peak-age alloy and over-age alloy in the $0.5 \% \mathrm{NaCl}$ solution.

along $\{111\} \alpha$. Alloying with $\mathrm{Mg}$ and $\mathrm{Ag}$ elements could facilitate precipitation of $\mathrm{T} 1$ ( $\left.\mathrm{Al}_{2} \mathrm{CuLi}\right)$ [22]. Size of particle $P$ shown in Figure 9 a was close to $100 \mathrm{~nm}$. Through elemental mapping (Figure 9b, Figure 9c and Figure 9d), the particle P contained $\mathrm{Al}, \mathrm{Cu}$ and $\mathrm{Mn}$ elements. Moreover, Skolianos, et al. [23] reported that scattered and tiny $\mathrm{Al}_{20} \mathrm{Cu}_{2} \mathrm{Mn}_{3}$ precipitates formed in as-cast Al-4.5Cu-2.0Mn alloys. Therefore, the particles $\mathrm{P}$ could be identified as $\mathrm{Al}_{20} \mathrm{Cu}_{2} \mathrm{Mn}_{3}$.

\section{Corrosion Resistance}

Figure 10 and Figure 11 presented typical Tafel curves of the peakage alloy and the over-age alloy which was first aged at $120^{\circ} \mathrm{C}$ for 4 hours and then aged at $180{ }^{\circ} \mathrm{C}$ for 16 hours. The electrolyte solutions were $0.5 \% \mathrm{NaCl}$ and $3.5 \% \mathrm{NaCl}$ in water. Tafel polarization parameters were shown in Table 3 and Table 4. All of the aged alloys demonstrated typical Tafel curves of aluminum alloys. The Tafel polariza- tion parameters in Table 4 indicated that the corrosion potential $\left(\mathrm{E}_{\text {corr }}\right)$ of the aged alloy gradually decreased with the increase of the second-stage aging time in $3.5 \% \mathrm{NaCl}$ solution. $\mathrm{E}_{\text {corr }}$ of the peak-age alloy and the over-age alloy was $-611 \mathrm{mV}$ and -653 $m V$, respectively. It could be inferred that the peakage alloy was easier to be corroded than the peakaged alloy did. Meanwhile, the over-age alloy also had higher corrosion current density $\left(I_{\text {corr }}\right)$, which indicated that the corrosion speed of the over-age alloys in $3.5 \% \mathrm{NaCl}$ solution was faster than that of the peak-age alloy. According to Table 3, $\mathrm{E}_{\text {corr }}$ of peak-age alloy in $0.5 \% \mathrm{NaCl}$ solution was $-573 \mathrm{mV}$ and $\mathrm{E}_{\text {corr }}$ of over-age alloy in $0.5 \% \mathrm{NaCl}$ solution was $-557 \mathrm{mV}$. The $\mathrm{E}_{\text {corr }}$ of peak-age alloy and over-age alloy in $0.5 \% \mathrm{NaCl}$ solution was both more positive than those in $3.5 \% \mathrm{NaCl}$ solution. And in $0.5 \% \mathrm{NaCl}$ solution, $\mathrm{E}_{\text {corr }}$ of over-age alloy was more positive than that of the peak-age alloy, and the over-age alloy also had higher $I_{\text {corr }}$ which also meant the 


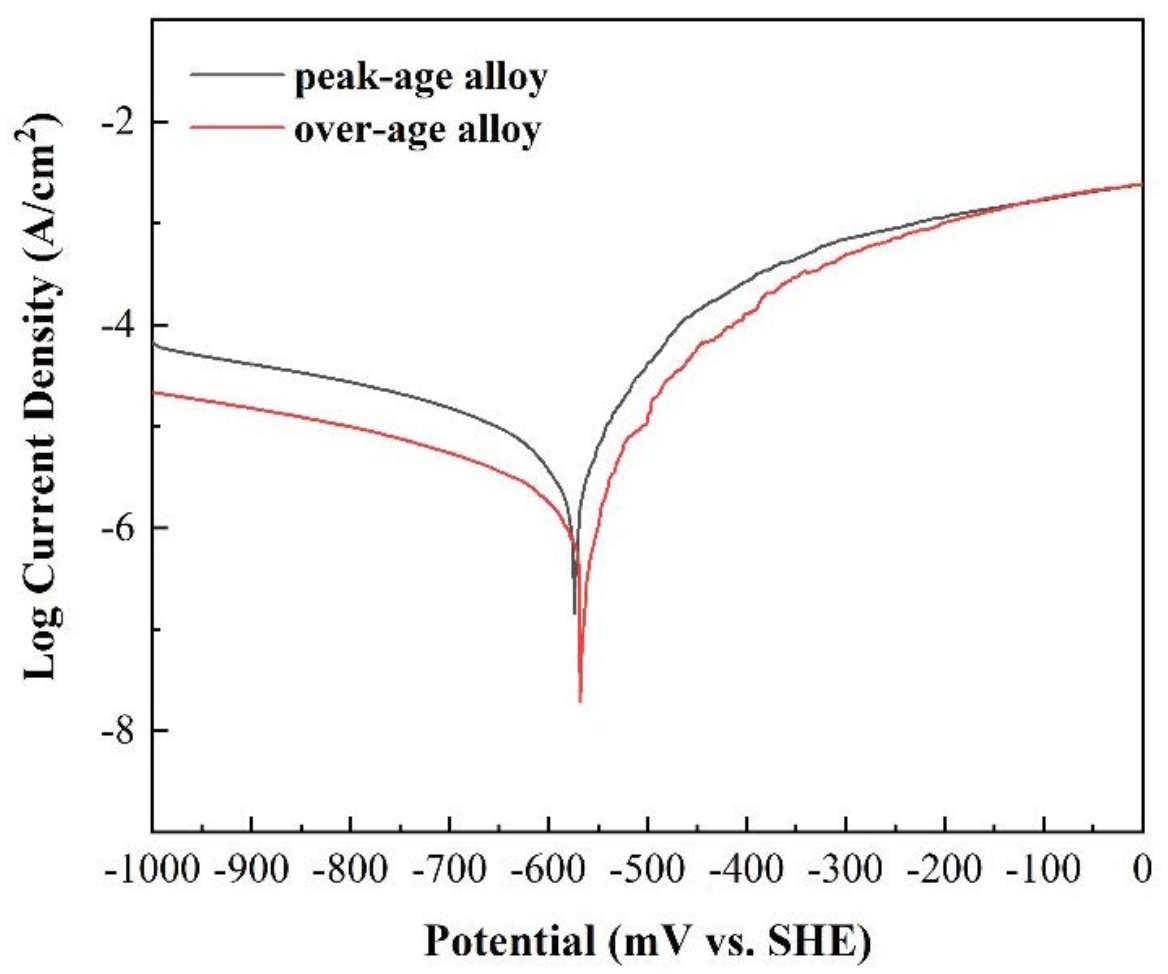

Figure 11: Typical tafel polarization curve of peak-age alloy and over-age alloy in the $3.5 \% \mathrm{NaCl}$ solution.
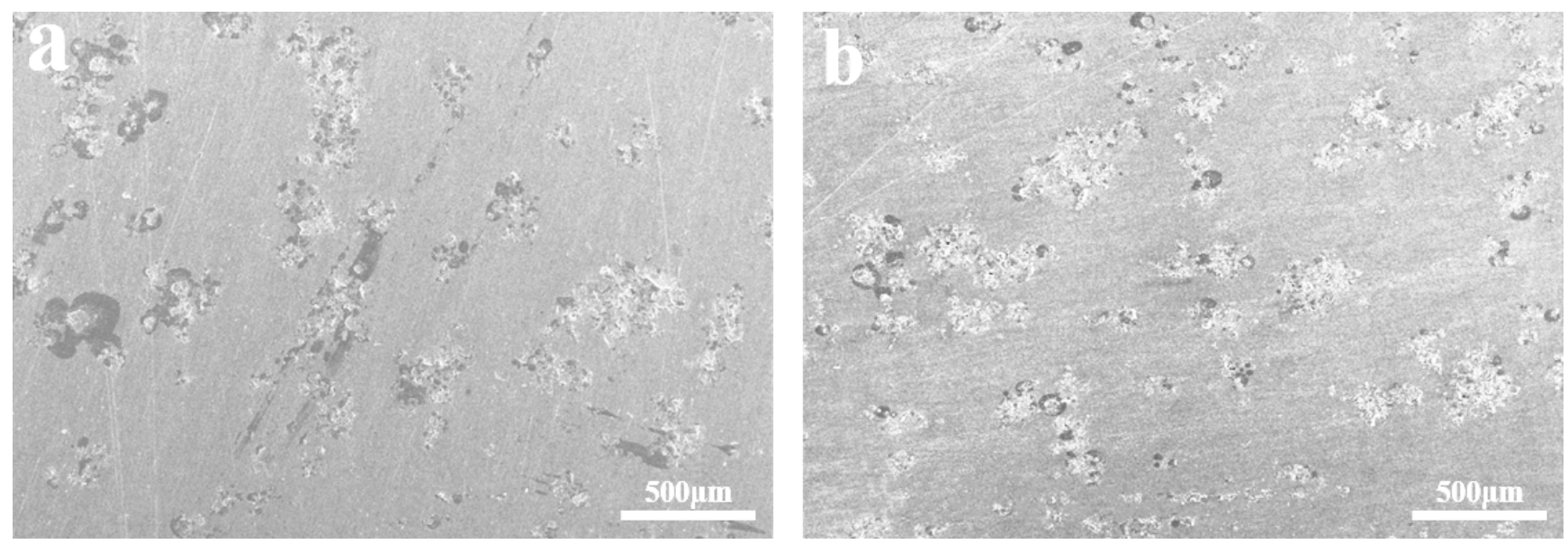

Figure 12: Corrosion surface of the alloy tested in the $0.5 \% \mathrm{NaCl}$ solution: (a) Peak-age; (b) Over-age alloys.

over-age alloy had higher corrosion speed.

The corrosion surface of aged alloys tested in $0.5 \% \mathrm{NaCl}$ solution was shown in Figure 12 and Figure 13. Compared to Figure $14 \mathrm{a}$ and Figure 14b, Figure $12 \mathrm{a}$ and Figure $12 \mathrm{~b}$ showed different morphology. In Figure 12a and Figure 12b, the corrosion area was wider than the pits in Figure 14a and Figure 14b. Meanwhile, Figure 12b presented more corrosion areas than those in Figure 12a, which indicates that the over-age alloy showed higher corrosion degree when the aged alloys were tested in $0.5 \% \mathrm{NaCl}$ solution. Moreover, in Figure 13a and
Figure 13b, the corrosion areas showed bubble-like surface, and there were cracks in the bubbles, which means that the solution of electrolyte was too low to present pitting corrosion. In Figure 13a, one bubble in images fractured and became shallow pits. The scale of bubbles was smaller than the pits in Figure 15a and Figure 15b, and bubbles in Figure 13b were bigger than bubbles in Figure 13a, which shows that over-age alloy presented higher corrosion degree.

The corrosion surfaces of aged alloys tested in $3.5 \% \mathrm{NaCl}$ solution are shown in Figure 14 and Fig- 

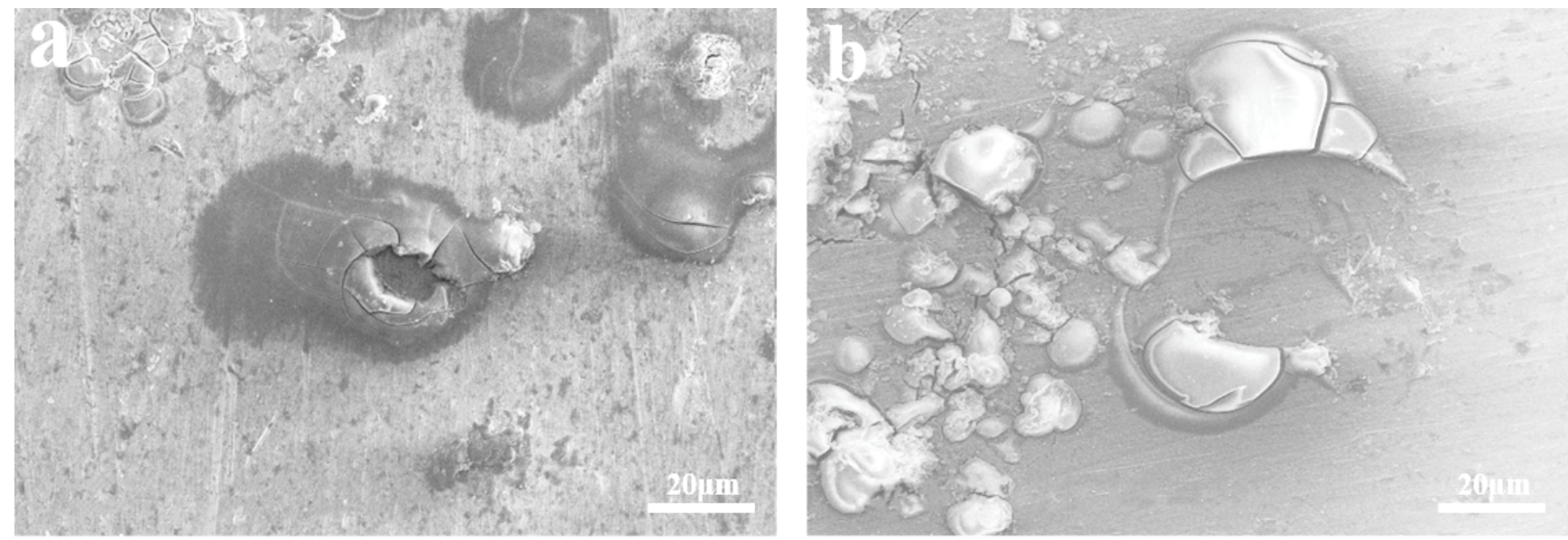

Figure 13: Corrosion pits of the alloy tested in the $0.5 \% \mathrm{NaCl}$ solution: (a) Peak-age; (b) Over-age alloys.
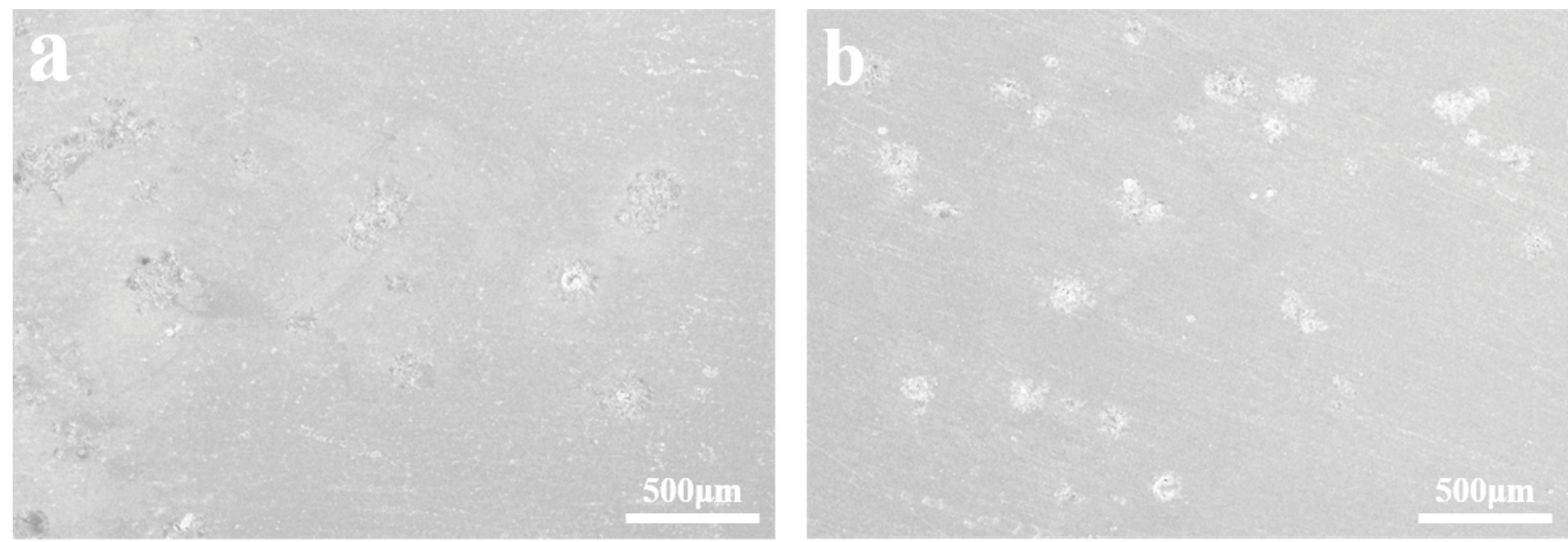

Figure 14: Corrosion surfaces of the alloy tested in the 3.5\% NaCl solution: (a) Peak-age alloy; (b) Over-age alloy.
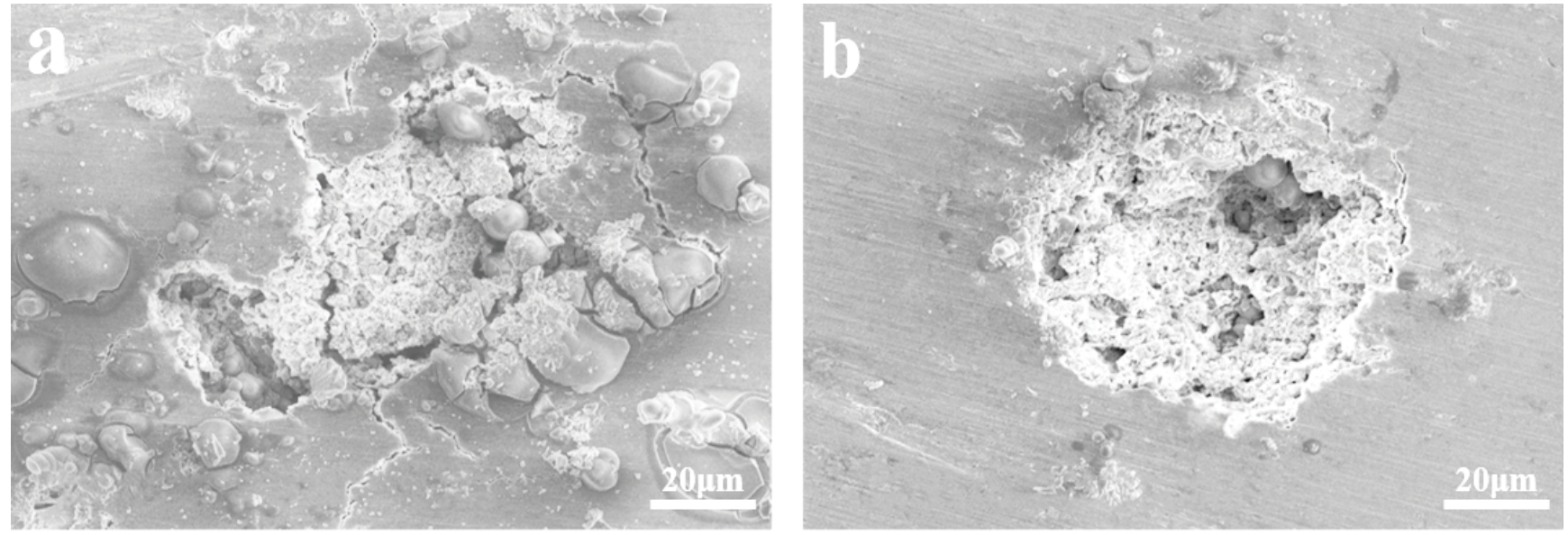

Figure 15: Corrosion pits of the alloy tested in the 3.5\% NaCl solution: (a) Peak-age; (b) Over-age alloy.

ure 15. The aged alloys presented pitting corrosion. Comparing Figure 14a with Figure 14b, there were differences in the number of corrosion pits for different aging treatment. The over-age alloys showed more corrosion pits than those of the peak-age alloys. Meanwhile, Figure 15a and Figure 15b also show high-magnification images of the corrosion pit. The pit of the over-age alloy was much bigger 
than that of the peak-age alloy, and the pit number of the over-age alloy was much higher than that of the peak-age alloy. The number of corrosion pits and the size of pit could reflect the degree of corrosion. Therefore, the corrosion of the aged alloy became more sever which was consistent with the Tafel curves and Tafel polarization parameters. Commonly, the bigger second phase was, the more sever corrosion was [24-26]. Consequently, the sever corrosion of the over-age alloy also reflected the bigger second phases in over-age alloy.

Thus, we could infer that the aged alloys tended to pitting corrosion. When the aged alloys were tested in $0.5 \% \mathrm{NaCl}$ solution, surface of the aged alloy presented bubble-like corrosion trace. And when the aged alloys were tested in $3.5 \% \mathrm{NaCl}$ solution, pits showed up. In the experiment tested in $0.5 \% \mathrm{NaCl}$ solution, the concentration of electrolyte was too low to form pits, and the bubbles should be the undamaged oxide film of the aged alloys. In general, the over-age alloy both presented higher corrosion degree and higher corrosion speed.

\section{Conclusion}

The Al-4.5Cu-1Li-0.4Mg-0.4Ag-0.4Mn-0.5Zn alloying with $\mathrm{Zr}$ and $\mathrm{Ti}$ elements should be homogenized at temperature lowering than $520{ }^{\circ} \mathrm{C}$ for avoiding over-burning. The phase precipitations during homogenization treatment were abundant and dispersed. $\mathrm{Al}_{7} \mathrm{Cu}_{4} \mathrm{Li}, \mathrm{Al}_{3} \mathrm{Li}$ and $\mathrm{Al}_{2} \mathrm{CuLi}$ were the main precipitates in the homogenized alloys. With the increase of homogenization temperature and holding time, the $\mathrm{Al}_{7} \mathrm{Cu}_{4} \mathrm{Li}$ precipitates gradually coarsened, the quantity of $\mathrm{Al}_{3} \mathrm{Li}$ precipitates increased and the $\mathrm{Al}_{2} \mathrm{CuLi}$ precipitates grew up. Moreover, $\mathrm{Zn}$ and $\mathrm{Mn}$ segregations were found in the $\mathrm{Cu}$-rich second phases.

After solution treatment and two-stage age treatment of the hot-extruded alloys, the hardness of aged alloy was gradually enhanced before the aging time approached 10 hours. Peak-age could occur after the alloy was first aged at $120^{\circ} \mathrm{C}$ for 4 hours and then aged at $180{ }^{\circ} \mathrm{C}$ for 10 hours. The peak-age alloy was mainly composed of $\mathrm{Al}_{2} \mathrm{CuLi}, \mathrm{Al}$ ${ }_{20} \mathrm{Cu}_{2} \mathrm{Mn}_{3}$ precipitates and $\mathrm{Cu}$-rich precipitates with large size.

The Tafel testing indicated that the corrosion potential could be enhanced with the increase of aging time, but the over-aged alloys presented high- er corrosion speed. In the $0.5 \% \mathrm{NaCl}$ solution, the aged alloys presented bubble-like corrosion trace. And the alloys tested in the $3.5 \% \mathrm{NaCl}$ solution presented corrosion pits on surface of the alloys.

\section{Acknowledgments}

This work was supported by the Open Research Fund (No. ZN2019006) of Science and Technology on High Strength Structural Materials Laboratory, Central South University, China. The authors would like to thank the Instrumental Analysis Center of Shanghai Jiao Tong University for SEM experiments.

\section{References}

1. Starke EA, Staley JT (1996) Application of modern aluminums to aircraft. Aerosp Sci 32: 131-172.

2. Rioja RJ (1998) Fabrication methods to manufacture isotropic Al-Li alloys and products for space and aerospace applications. Mater Sci Eng A 257: 100-107.

3. Rioja RJ, Liu J (2012) The Evolution of Al-Li base products for aerospace and space applications. Metall Mater Trans A 43: 3325-3337.

4. Bennett CG, Lynch SP (1998) Fracture toughness of $2090 \mathrm{Al}-\mathrm{Li}-\mathrm{Cu}$ extrusions with high and low hydrogen contents. Mater Sci Eng A 247: 32-39.

5. Peng DL, Lu Z, An GY, Zhou B (1994) The Influence of airconium on the structure and mechanical properties in Al-Li-Cu alloy. Foundry 7: 23-26.

6. Yu TF, Qian BY, Wu RZ, Sun JF, Zhao H (2020) Microstructure and mechanical properties of the as-cast Al-Li-Cu-Mg-Zr alloy with high Li content and different $\mathrm{Cu} / \mathrm{Mg}$ ratios. Adv Eng Mater 22: 1901570.

7. Zhao TZ, Jin L, Gao TJ, Liu CZ (2019) Smelting, rolling and heating treatment of $2198 \mathrm{Al}$-Li alloy. Rare Metal Mater Eng 48: 2305-2309.

8. Mishra S, Suresh M, More AM, Bisht A, Nayan N, et al. (2021) Texture control to reduce yield strength anisotropy in the third generation aluminum-copper-lithium ally: Experiments and modeling. Mater Sci Eng A 799: 140047.

9. Lee SM, Pyun SI (1990) Effects of microstructure and strain rate on hydrogen-assisted cracking of Al-1.9\%Li alloy. J Mater Sci Lett 9: 1247-1250.

10.Saikawa S, Nakai K, Sugiura Y, Kamio A (1999) Effect of hydrogen gas on generation of porosity in Al-Li casting alloys. Mater Trans Jim 40: 57-63.

11.Gupta RK, Nayan N, Nagasireesha G, Sharma SC (2006) Development and characterization of Al-Li alloys. Mater Sci Eng A 420: 228-234. 
12.Pitcher PD (1988) Ageing of forged aluminium-lithium 8091 alloy. Scripta Metal 22: 1301-1306.

13.Cina B, Ranish B (1974) New technique for reducing susceptibility to stress corrosion of high strength aluminum alloys. Alum Ind Pro 27: 79-84.

14.Ahmadi S, Arabi H, Shokuhfar A (2010) Effects of multiple strengthening treatments on mechanical properties and stability of nanoscale precipitated phases in an aluminum-copper-lithium alloy. J Mater Sci Tech 26: 1078-1082.

15.Liu Q, Zhu RH, Zhang L, Zheng ZQ, Chen Yl, et al. (2016) Microstructural evolution of $\mathrm{Mg}, \mathrm{Ag}$ and $\mathrm{Zn}$ micro-alloyed Al-Cu-Li alloy during homogenization. Trans Nonferrous Met Soc China 26: 607-619.

16.Wu L, Li XF, Wang HW (2021) The effect of major constituents on microstructure and mechanical properties of cast Al-Li-Cu-Zr alloy. Mater Chara 171: 110800.

17.Luo L, Luo LS, Li ZP, Su YQ, Xia HY, et al. (2010) Microstructural evolution of Al-Cu-Li alloys with different Li contents by coupling of near-rapid solidification and two-stage homogenization treatment. Chin Found Res Develop 17: 190-197.

18. Kilmer RJ, Stoner GE (1991) Effect of Zn additions on precipitation during aging of alloy 8090 . Scrip Mater 25: 243-248.

19.Wei YY, Zheng ZQ, Chen ZG (2008) Trace Mg and Zn additions on microstructure and mechanical properties of an Al-Cu-Li-Mn-Zr alloy. In: WILEY-VCH GmbH
\& Co KGaA, Proceedings of the international conference on aluminum alloys. ( $11^{\text {th }}$ edn), Weinheim, 1050-1055.

20. Hajjari E, Divandari M (2008) An investigation on the microstructure and tensile properties of direct squeeze cast and gravity die cast 2024 wrought Al alloy. Mater Eng 29: 1685-1689.

21.Wang XM, Shao WZ, Jiang JT, Li GA, Wang XY, et al. (2020) Quantitative analysis of the influences of pre-treatments on the microstructure evolution and mechanical properties during artificial age of an AlCu-Li-Mg-Ag alloy. Mater Sci Eng A 782: 139253.

22. Huang BP, Zheng ZQ (1998) Independent and combined roles of trace $\mathrm{Mg}$ and $\mathrm{Ag}$ additions in properties precipitation process and precipitation kinetics of Al-Cu-Li-(Mg)-(Ag)-Zr-Ti alloys. Acta Mater 46: 4381-4393.

23.Skolianos SM, Katramis TZ, Devereux OF (1989) Microstructure and corrosion behavior of as-cast and heat-treated Al-4.5Cu-2.0Mn alloys. Metall Trans A 20: 2499-2516.

24. Ralston KD, Fabijanic D, Birbilis N (2011) Effect of grain size on corrosion of high purity aluminium. Electrochemical Acta 56: 1729-1736.

25. Ma YL, Zhou XR, Huang WJ (2015) Localized corrosion in AA2099-T83 aluminum-lithium alloy: The role of intermetallic particles. Mater Chem Phys 161: 201-210.

26.Zaid B, Saidi D, Benzaid A (2008) Effects of pH and chloride concentration on pitting corrosion of AA6061 aluminum alloy. Cor Sci 50: 1841-1847. 